\title{
Volunteers in emergency management: an investment in the future?
}

\author{
J. Dostál $1^{1} \&$ L. Balarinová ${ }^{2}$ \\ ${ }^{I}$ Faculty of Economics and Administration, \\ Masaryk University, Czech Republic \\ ${ }^{2}$ Faculty of Health Sciences, \\ Palacký University in Olomouc, Czech Republic
}

\begin{abstract}
There are currently two interconnected and conflicting challenges in many countries in the world: emergency and disaster preparedness and the public finance crisis. Volunteers are a valuable and necessary resource for emergency and disaster management. This paper deals with various experiences and emergencies in the Czech Republic in which the nonprofit sector is significantly involved. The aim of the paper is to identify the scope of Czech emergency volunteering and its role in the national Integrated Rescue System (IRS). The Czech IRS is a well-established system based partly on volunteers. The volunteer-to-professional ratio is nearly 12 to 1 for firefighters and about 3.6 to 1 for the mountain rescue service; the water rescue service consists exclusively of volunteers. Moreover, hundreds or thousands of people volunteer during large floods. The scope of volunteer engagement during emergency situations can also be illustrated through estimates of its economic value. The Czech Republic saves public finances for operational expenditures of parties of the IRS, because these costs could be lowered with volunteer participation. It is possible to consider past investments in emergency volunteering as investments in the high-functioning IRS. Analogically, current investments in emergency volunteering can and should be considered as investments in sustaining the current activities of the IRS. The Czech model should be explored more thoroughly; it could be interesting for other countries with problems in emergency and disaster response, especially countries that need to reduce public expenditures.

Keywords: volunteers, emergency management, investments, the Czech Republic, rescue system, economic value of volunteering.
\end{abstract}




\section{Introduction}

An overwhelming majority of countries throughout the world are coping with two problems: emergencies or even disasters and the financial crisis. Countries spend public funds to resolve the consequences of emergencies and disasters; however, the financial crisis creates pressure to decrease public expenditures. In this situation, another, non-monetary source comes into consideration to address emergencies and disasters, which is volunteering.

Currently, emergency volunteering is most commonly done through volunteer organizations (non-governmental, non-profit organizations - NGOs). The existence of these organizations is influenced by national policies. Communism was installed in a considerable part of the world in the past century. Palubinskas [1] wrote that the implementation of communism in Central and Eastern Europe resulted in the virtual elimination of NGOs. The NGOs that were not dissolved by communist regimes gradually came under their control. Although some NGOs continued operating, for example the Czech Red Cross and Caritas, they were not truly NGOs because they were not independent of the state. After the fall of communist regimes, these organizations had to learn to function as NGOs again, which means, among other things, that they had to acquire a private character and be independent of the state.

The Czech Republic is a former Eastern bloc country where the communist regime collapsed in November 1989. Czech NGOs, including humanitarian ones, were in a kind of stasis then. Large-scale flooding requiring massive humanitarian aid had not occurred in (then) Czechoslovakia for decades, and humanitarian aid in the country had been fully under the baton of the state during the communist regime (Rektořík et al. [2]).

Volunteer firefighting continued in the Czech Republic under the communist regime and this tradition has continued to a considerable extent to the present day, and volunteer firefighters form an integral part of the firefighting service in the Czech Republic (Kavan et al. [3])

Apart from ordinary emergencies such as fires and traffic accidents, the Czech Republic also has to cope with accidents occurring in its mountains and on its watercourses (rivers, lakes, dams, etc.). These are areas where volunteers play an irreplaceable role performing rescue work.

The most devastating natural disasters in the Czech Republic are floods. The Czech Republic was hit by eight large floods between 1997 and 2010, with 116 casualties and damages costing close to CZK 172 billion (about EUR 6.65 billion) (Rektořík et al. [2])

NGOs and their volunteers have become an integral part of the Integrated Rescue System. Their activities require funding, or they cannot in some matters further develop their operations. The costs for volunteers include insurance, training, etc. For specialized volunteers, such as volunteer firefighters and rescue workers, the costs additionally include equipment. These costs are partially covered by donations and partially from public sources.

Enormous progress has been recently made in methods for measuring the economic value of volunteering. For example, Stiglitz et al. [4], Waring [5], and 
Soupourmas and Ironmonger [6] concluded that traditional indicators such as GDP are insufficient measures of contemporary economic performance. These traditional indicators do not include values other than market production, such as volunteering, which has its own specific value, as noted by Sues and Wilson [7], Emanuele [8], Steinberg [9], Femida and Narasimhan [10], Brown [11], Ross [12] and Montmarquette and Monty [13]. According to Salamon et al. [14], Colman [15], Soupourmas and Ironmonger [6] and Novák [16], the value of volunteerism is measurable and it is advisable to measure it. For this reason, the economic value of volunteering will be estimated in selected cases in this article.

The objective of this article is to identify the scope of volunteer engagement during emergencies in the Czech Republic and the role of volunteerism in the country's Integrated Rescue System (IRS).

\section{Materials and methods}

The role of NGOs in the IRS will be identified through the links between NGOs and their volunteers within the IRS, in terms of both the legal (theoretical) and factual (practical) aspects. The scope of volunteering in emergencies will be determined by comparing the number of volunteers to the number of paid staff in a specific area and by estimating the economic value of selected types of volunteering.

The work methodology is based on bibliographic research and research of available internet resources and on estimations of the economic value of voluntary work during emergencies.

The estimations were made using the methodology of the Czech Statistical Office, which is in compliance with the International Labour Organization (ILO) methodology [17]. The approach measures inputs in the form of volunteer work by means of replacement costs, when the selected type of replacement cost is the generalist wage. This approach was selected for its analytical simplicity. Basically, this evaluates the time invested by volunteers as the main input of their work. The replacement wage is the median hourly wage in the non-profit sector. Two basic types of data are required for calculation: the number of volunteer hours and the replacement median hourly wage in the particular economy or, more specifically, in its non-profit sector. In the Czech Republic, this data is available in the Average Earnings Information System kept by the Ministry of Labour and Social Affairs.

The calculation involves multiplying the number of volunteer hours by the replacement hourly wage.

$$
\mathrm{V}=\mathrm{t} * \mathrm{w}
$$

$\mathrm{V}$ The economic value of volunteering;

$t \quad$ The number of volunteer hours;

w The replacement median hourly wage in the given economy.

This method may be used to estimate the values of volunteer work performed both by volunteers of individual organizations and the whole volunteer sector 
during emergencies when we have necessary data available. However, a substantial lack of data on volunteer hours is a problem in many countries, including the Czech Republic. The examples mentioned in this paper are exceptional. Although figures concerning total volunteer hours are not available in some cases, they may be count on the basis of the figure about the total number of volunteers and the number of volunteer hours which the volunteers were working per day.

The paper uses the definition of volunteering by Salamon et al. [14] and the ILO [17], according to which volunteering is "unpaid non-compulsory work; that is time individuals give without pay to activities performed either through an organization or directly for others outside their own household."

\section{Results}

Emergency volunteering is practically a phenomenon in the Czech Republic. Thousands of volunteers are involved during any large-scale flooding, and tens of thousands more annually serve as volunteer firefighters and rescue workers. We present the role of volunteers during emergencies in the Integrated Rescue System (IRS) of the Czech Republic and the scope of the volunteering.

\subsection{The role of volunteers in IRS}

The Integrated Rescue System of the Czech Republic is not an institution, state agency, association, or legal entity. It is a system of connections and rules for cooperation and coordination of rescue and safety forces, public administration bodies, natural persons, and legal entities in jointly performed rescue and cleanup operations and emergency preparation. It is governed by Act 239/2000 Coll., on the Integrated Rescue System (IRS) [18].

The Act provides for the main and subsidiary components of IRS, classifying non-governmental non-profit organizations (NGOs) among the subsidiary components that may be used for rescue and clean-up operations. The NGOs use volunteers for these activities. Results from previous research (Dostál [19]) indicate that the engagement of NGOs and volunteers in the IRS is both theoretically possible and implemented in practice. Volunteer firefighters and paramedics are usually directly involved in rescue operations, and the "standard" volunteers are involved in flood clean up or in providing humanitarian aid, with the NGOs mediating their assistance often involved in regional or municipal emergency plans. Through their representatives, volunteer NGOs participate in meetings of respective task forces and the Panel, a coordination platform where representatives of NGOs and the public administration meet to coordinate the assistance provided by NGOs, including volunteer aid.

\subsection{The scope of volunteering during emergencies in the Czech Republic}

The scope of volunteering during emergencies in the Czech Republic will be shown by numbers of volunteers and by measuring the economic value of their 
work. The economic value will be based on the methodology of the Czech Statistical Office which complies with the methodology of the ILO [17].

\subsection{1 "Standard" volunteering during floods}

These volunteers perform activities that are mostly unqualified in terms of knowledge and skills, such as waste matter removal, cleaning operations, monitoring of the situation, assistance in distributing in-kind aid, assistance in organizing in a specific municipality, or supporting (listening to) people affected by flooding (Koláček and Diatková [20]). Thousands of volunteers participate under various NGOs during any large-scale flooding. Two examples of such engagement with the necessary data available are People in Need, a nongovernmental organization, during the floods in 2002, and ADRA in 2010.

3.2.1.1 Volunteers of the people in need during the floods in 2002 More than 3,000 volunteers, working a total of about 150,000 volunteer hours, were engaged through the People in Need during the floods. [21] We use the equation in the Materials and Methods section to measure the economic value of those volunteers. The total number of hours was 150,000 , and the replacement median hourly wage for 2002 was CZK 90.15 [22].

$$
\begin{gathered}
\mathrm{TV}=150,000 * 90,15 \\
\mathrm{TV}=13,522,500
\end{gathered}
$$

The estimated economic value of volunteers of the People in Need during the floods in 2002 is CZK 13,522,500 (about EUR 523,013).

3.2.1.2 ADRA volunteers during the floods in August 2010 The exact number of volunteer hours for ADRA during the 2010 floods is not known, but it can be calculated. Chodurová [23] states that ADRA sent out more than 1,200 volunteers during these floods, hence we will proceed from the presumption that there were 1,200 volunteers of ADRA. The volunteers operated in the Liberec region from August 7 to September 11, 2010, with a median number of four 8hour days per volunteer [23].

Tt The total number of ADRA volunteer hours during the floods;

1,200 The total number of ADRA volunteers during the floods;

4 The median number of ADRA volunteer days during the floods;

8 The average number of ADRA volunteer hours during the floods.

$$
\begin{gathered}
\mathrm{Tt}=1,200 * 4 * 8 \\
\mathrm{Tt}=38,400
\end{gathered}
$$

The estimated number of volunteer hours worked by ADRA volunteers is 38,400. The replacement median hourly wage for 2010 was CZK 137.34 [24]. We use those figures to estimate the economic value of ADRA volunteers during the floods in August 2010.

$$
\begin{gathered}
\mathrm{TV}=38,400 * 137.34 \\
\mathrm{TV}=5,273,856
\end{gathered}
$$


The estimated economic value of the volunteers in 2010 is CZK 5,273,856 (about EUR 203,978).

These two examples serve to illustrate that even volunteering in the form of unqualified activities implies a considerable economic value.

\subsubsection{Volunteer rescue workers}

There are a number of volunteer rescue workers in the Czech Republic. The two main types, mountain rescue service and water rescue service, are described in detail below. Rescue workers providing specialized services in various situations, such as disasters and cave accidents (speleological rescue service), emergencies requiring dog experts (rescue brigades of cynologists), etc. also operate in the Czech Republic.

3.2.2.1 Mountain Rescue Service The Mountain Rescue Service of the Czech Republic has about 110 professional and approximately 400 volunteer members [25]. This means that there are about 3.6 volunteer rescue workers per one professional. Their work is highly specialized; the mountain rescue service members include various specialists.

To estimate the economic value of volunteers for the mountain rescue service, we need to know the total number of hours they worked. The figure is not available, but it may be estimated.

Approximately 400 volunteers operated in the mountain rescue service in 2011 [25], although there are no available data on the number of hours they worked or estimates of the economic value of their work. Volunteers of the mountain rescue service work 20 to 25 days a year on average; we will use the average of those numbers: 22.5 days a year. The working day of a volunteer usually lasts 8 hours [26]. We multiply the estimated total number of volunteer hours (Tt) with the replacement hourly wage, which was CZK 140.75 for 2011 [27].

$$
\begin{gathered}
\mathrm{TV}=72,000 * 140.75 \\
\mathrm{TV}=10,134,000
\end{gathered}
$$

The estimated economic value of volunteer work performed by volunteers of the mountain rescue service in 2011 is CZK 10,134,000 (approximately EUR 391,955).

3.2.2.2 Water Rescue Service This is another area where volunteer rescue workers are significantly engaged. With 1,450 members, the Water Rescue Service of the Czech Red Cross (WRS CRC) is the main player in this field [3]. There are no professional water rescue workers in the Czech Republic; therefore the water rescue service in the country is performed exclusively by volunteers. Data about the number of adult volunteers of the Water Rescue Service and the hours they worked are available for 2004.

In 2004, 770 adult volunteers worked 72,907 hours for the Water Rescue Service and according the estimate of WRS CRC, the property valued at several millions of CZK was rescued [28]. Let us however have a look now at the 
estimate by means of the methodology of the Czech Statistical Office. The replacement median hourly wage was CZK 106.73 for 2004 [29].

$$
\begin{gathered}
\mathrm{TV}=72,907 * 106.73 \\
\mathrm{TV}=7,781,364.11
\end{gathered}
$$

The estimate of the economic value of volunteers of the Water Rescue Service of the Czech Red Cross for 2004 is CZK 7,781,364.11 (approximately EUR 300,961).

3.2.2.3 Volunteer firefighters Currently, there are about 75,000 volunteer firefighters in the Czech Republic plus more than 300,000 other members of the volunteer firefighters association. There are about 9,000 professional firefighters in the Czech Republic, out of whom approximately 6,400 are those who are going to intervene to in case of emergency (Dostál and Hrůza [30]). Significance of volunteer firefighting will be explicated using the example of the district of Mělník, comprising nearly one hundredth of the territory of the Czech Republic. The following table provides detailed information about the district.

Table 1: Volunteer firefighters in the district of Mělník within the context of the Czech Republic.

\begin{tabular}{|l|c|c|c|}
\hline & District of Mělník & CR & Ratio \\
\hline Area & $701.08 \mathrm{~km}^{2}$ & $78,867 \mathrm{~km}^{2}$ & $1 / 112$ \\
\hline Inhabitants & $104,169 \mathrm{~km}^{2}$ & $10,505,445 \mathrm{~km}^{2}$ & $1 / 101$ \\
\hline Number of volunteer firefighters & 3,768 & 75,000 & $1 / 20$ \\
\hline Number of hours worked & 26,448 & N/A & N/A \\
\hline $\begin{array}{l}\text { Number of volunteer firefighters } \\
\text { units }\end{array}$ & 31 & N/A & N/A \\
\hline $\begin{array}{l}\text { Number of interventions by } \\
\text { volunteer firefighters }\end{array}$ & 548 & N/A & N/A \\
\hline $\begin{array}{l}\text { Volunteer work value (CZK) } \\
\text { CZK 3,598,779 } \\
\text { (EUR 139,190) }\end{array}$ & N/A \\
\hline
\end{tabular}

Source: drawn up by the authors on the basis of [31].

This component of volunteer firefighting in the Czech Republic was selected due to the availability of aggregate data at least for one whole district. Usually, data about the number of volunteer hours are inconsistently available and only for individual units.

We know the number of volunteer hours, and the replacement median hourly wage was CZK 136.07 for 2012 (the $1^{\text {st }}$ term) [32].

$$
\begin{gathered}
\mathrm{TV}=26,448 * 136.07 \\
\mathrm{TV}=3,598,779.36
\end{gathered}
$$

The economic value of firefighters in a single district of the Czech Republic was CZK 3,598,779.36 (approximately EUR 139,190). However, there are about 20 times more volunteer firefighters in the Czech Republic. Hence, the economic 
value of volunteer firefighting in the whole Czech Republic is certainly higher. If all volunteer firefighters in the Czech Republic worked on average the same number of hours, the economic value of all volunteer firefighters in the Czech Republic would be CZK 71,975,587.2 (about EUR 2,783,816).

\section{Conclusion}

Volunteers in emergencies save significant public expenses. . Table 2 summarizes data about selected examples of volunteering, specifically the number of volunteer hours, the estimated economic value of individual examples of volunteering, and the ratio of volunteers to professionals.

Table 2: $\quad$ Scale of emergency volunteering in the Czech Republic.

\begin{tabular}{|l|c|c|c|c|}
\hline NGO & Year & $\begin{array}{c}\text { Number of } \\
\text { volunteer hours }\end{array}$ & $\begin{array}{c}\text { Economic } \\
\text { value (EUR) }\end{array}$ & $\begin{array}{c}\text { Volunteer to } \\
\text { professional } \\
\text { ratio }\end{array}$ \\
\hline $\begin{array}{l}\text { People in Need during } \\
\text { floods }\end{array}$ & 2002 & $\begin{array}{c}150,000 \text { during } \\
\text { the flood }\end{array}$ & 523,013 & N/A \\
\hline Water Rescue Service & 2004 & $\begin{array}{c}72,907 \text { for the } \\
\text { year }\end{array}$ & 300,961 & $\begin{array}{c}\text { Exclusively } \\
\text { volunteers }\end{array}$ \\
\hline ADRA during floods & 2010 & $\begin{array}{c}38,400 \text { during the } \\
\text { flood }\end{array}$ & 203,978 & N/A \\
\hline Mountain Rescue Service & 2011 & $\begin{array}{c}72,000 \text { for the } \\
\text { year }\end{array}$ & 391,955 & 3.64 to 1 \\
\hline $\begin{array}{l}\text { Volunteer firefighters in } \\
\text { the District of Mělník } \\
\text { (1/112 the territory of CR) }\end{array}$ & 2012 & $\begin{array}{c}26,448 \text { for the } \\
\text { year }\end{array}$ & 139,190 & 11.72 to 1 \\
\hline
\end{tabular}

Source: calculations by the authors.

Failure to provide volunteer aid in emergencies would probably have fatal impacts on the Integrated Rescue System of the Czech Republic, especially on the provision of water rescue services, mountain rescue services, and fire protection. The decrease in human resources to cope with consequences of flooding would also be considerable.

The paper estimates the economic value of selected types of volunteering in emergencies. The initial estimates show a considerable economic value, running to hundreds of thousands of euro for individual types of volunteering. The gross estimates for the total volunteer firefighting in the Czech Republic amount to millions of euro annually.

Although volunteers perform their activities free of charge, certain financial means are required to fund them. Volunteers during floods must get to the site where they will provide assistance; ideally they are also insured and trained. Volunteer firefighters and rescue workers need equipment and qualification requirements lead to a considerably higher need for training which also requires 
some funding. Because volunteers in these cases perform functions that the state is responsible for, the logical funding for these costs are public budgets.

Public expenditures cover part of the costs of the volunteering. However, the financial support may not be considered only to be support volunteering as a free-time activity which is helping the volunteers, but also as investments to the Integrated Rescue Service of the Czech Republic. It is very likely that without the past investments in volunteering in emergencies, this part of the non-profit sector in the Czech Republic would be nowhere near as developed as it is. There is another point of view. If the state stopped supporting volunteering in emergencies and the volunteer activities were limited considerably, the Integrated Rescue System would be endangered by at least partial collapse. This connection is most marked for volunteer firefighters, whose activities require investments in equipment and vehicles, etc. To transfer the Czech model to other countries would require further analysis, but it can now be stated that the Czech model is, at least, an interesting example for any country that regularly suffers from emergencies and disasters, especially for those that feel pressure from decreasing public expenditures.

\section{References}

[1] Palubinskas, G.T., Democratization: The Development of Nongovernmental Organizations (NGOs) in Central and Eastern Europe, Public Administration and Management, 8(3), 2003.

[2] Rektořík, J., Šelešovský, J., Bakoš, E., Dostál, J., Furová, L., Šrámková, T. and Smutný, M., Zpráva z výzkumného projektu "Ekonomické a finanční dopady živelních pohrom”: Brno, 2011.

[3] Kavan, Š., Dostál, J., et al. Dobrovolnictví a nestátní neziskové organizace při mimořádných událostech $\mathrm{v}$ podmínkách Jihočeského kraje. Vysoká škola evropských a regionálních studií:, České Budějovice: p. 69. 2012.

[4] Stiglitz, J. E., Sen, A., and Fitoussi, J.-P. Report by the Commission on the Measurement of Economic Performance and Social Progress. Paris: CMEPSP (September). 2009.

[5] Waring, M. J., Counting for Nothing: What Men Value and What Women Are Worth. University of Toronto Press, 310 p. 1999.

[6] Soupourmas, F., and Ironmonger, D. Giving Time: the economic and Social Value of Volunteering in Victoria. Melbourne, xii, 95 p. 2002.

[7] Sues, A. M., and Wilson, P. Developing a Hospital's Volunteer Program. Health and Social Work, 12(1), 13-20. ISSN: 0360-7283. 1987.

[8] Emanuele, R., Is There a Downward Sloping Curve Demand Curve for Volunteer Labor? Annals of Public and Cooperative Economics, 67, 193208. ISSN: 1467-8292. 1996.

[9] Steinberg, R., Labor Eeconomics and the nonprofit Sector: A Literature Review. Nonprofit and Voluntary Sector Quarterly, 19, 151-169. ISSN: 0899-7640. 1990.

[10] Femida, H., and Narasihman, S., Valuing Volunteers: An Economic Evaluation of the Net Benefits of Hospital Volunteers. Nonprofit and 
Voluntary Sector Quarterly, March 2004, vol. 33 no. (1), pp. 28-54. ISSN: 0899-7640. 2004.

[11] Brown, E. Assessing the Value of Volunteer activity. Nonprofit and Voluntary Sector Quarterly, 28(1), pp. 3-17. ISSN: 0899-7640. 1999.

[12] Ross, D. How to Estimate the Economic Contribution of Volunteer Work. Ottawa, Canada: Voluntary Action Directorate, Department of Canadian Heritage. 1994.

[13] Montmarquette, C., and Monty, L., An empirical model of a household's choice of activities. Journal of Applied Economics, 2, pp. 145-158. 1987.

[14] Salamon, M. L., Sokolowski, W., and Haddock, M. A. Measuring the Economic Value of Volunteer Work Globally: Concepts, Estimates, and a Roadmap to the Future. Annals of Public and Cooperative Economics, 82(3): pp. 217-252. ISSN: 1467-8292. 2011.

[15] Colman, R., The Economic Value of Civic and Voluntary Work in Nova Scotia, GPI Atlantic, Halifax, 1998. Online: http://dspace.cigilibrary.org/ jspui/bitstream/123456789/19539/1/Economic\%20Value\%20of\%20Civic\% 20and $\% 20$ Voluntary $\% 20$ Work $\% 20$ in $\% 20$ Nova $\% 20$ Scotia.pdf? 1

[16] Novák, T. Metody oceňování dobrovolné práce. Acta Oeconomica Pragensia 1/2008. ISSN 0572-3043. Prague. 2008.

[17] International Labour Organization (ILO), 2011. Manual on the Measurement of Volunteer Work. International labour office Geneva. March 2011. Online: http://www.ilo.org/wcmsp5/groups/public/@dgreports /@stat/documents/publication

[18] Law no. 239/2000 on the Integrated Rescue System.

[19] Dostál, J., Cooperation between non-governmental organizations and the State in the matter of flood risk management in the Czech Republic. Flood Recovery, Innovation and Response III, eds. D. Proverbs, S. Mambretti, C.A. Brebbia, D. De Wrachien. WIT Press: Southampton, UK, pp. 15-26, 2012.

[20] Koláček, J. and Diatková, N.., Dobrovolnictví při mimořádných událostech In: Dobrovolník.cz: Oblasti dobrovolnictví. Online. [cited: 2013-04-23] http://www.dobrovolnik.cz/oblasti-dobrovolnictvi/dobrovolnictvi-vkrizovych-situacich

[21] Člověk v tísni. Výroční zpráva 2002. Online: http://www.clovekvtisni. cz/uploads/file/1358945785-pin_vz2002cz.pdf

[22] The Ministry of Labour and Social Affairs of the Czech Republic. The Information System on the Average Earnings: the Profit and Non-Profit Sectors - 4th Quarter]. 75 p. 2002. Online: http://www.ispv.cz/ getattachment/eefb660b-bf6a-443d-b2e9-69a632c47e65/Publikace-veformatu-PDF.aspx?disposition=attachment

[23] Chodurová, A. Evaluace dobrovolnické služby při povodni 2010 na Liberecku z pohledu dobrovolníků pomáhajících za organizaci ADRA 2002 Zlín, 2011. Online: http://dspace.k.utb.cz/bitstream/handle/10563/15525/ chodurov $\%$ C3\%A1 2011 dp.pdf? sequence $=1$

[24] The Ministry of Labour and Social Affairs of the Czech Republic]. The Information System on the Average Earnings: Salary Earners Sector - 1st 
Quarter 2010]. 68 pp. 2012. Online: http://www.ispv.cz/getattachment/ 391ae9da-5a89-4efd-a1ce-0d0fa2cfc99b/CR_122_PLS-pdf.aspx?

disposition=attachment

[25] The Mountain Rescue Service Is Ready for the Winter Season After a Demanding Year. In: Horská služba ČR. Prague, 2011, Online http://www.hscr.cz/index.php?option $=$ com_content\&task $=$ view\&id $=1562 \&$ Itemid $=$

[26] Interview with the Chief of the Mountain Rescue Service: cooperation with the fire rescue service is nearly minimal, unfortunately. Hasičské noviny. 2013, 1/2013, p. 2 Online: http://www.hasicskenoviny.cz/noviny13/ hn 01 13.pdf

[27] The Ministry of Labour and Social Affairs of the Czech Republic. The Information System on the Average Earnings: Salary Earners Sector]. 68 pp. 2011 Online: http://www.ispv.cz/getattachment/ebd28ea6-86e9-4322803a-d1adbbdd3ab5/CR 114 PLS-pdf.aspx?disposition=attachment

[28] Vodní záchranná služba ČČK. In Český Červený kříž . Online: http://www.cervenykriz.eu/cz/vzs.aspx

[29] The Ministry of Labour and Social Affairs of the Czech Republic. The Information System on the Average Earnings: Salary Earners Sector]. 54 pp. 2004. Online: http://www.ispv.cz/getattachment/c7f95102-3ce0-4e859c67-57a2ca4ba7a3/Publikace-ve-formatu-

PDF.aspx?disposition=attachment

[30] Dostál, J and Hrůza, F. Identifying the Importance of Measuring Monetary Value of Volunteering in the Czech Republic. In Furová L, \& Špalková, D. Proceedings of the 17th International Conference. Current Trends in Public Sector Research. Brno: Masarykova univerzita, s. 29-37, 320 s. ISBN 97880-210-6159-0. 2013.

[31] Dobrovolní hasiči okresu Mělník hodnotili svoji činnost za rok 2012. In: Oficiální portál Stredočeského kraje. 2013 Online: http://www.krstredocesky.cz/portal/aktuality/dobrovolni-hasici-okresu-melnik-hodnotilisvoji-cinnost-za-rok-2012.htm

[32] The Ministry of Labour and Social Affairs of the Czech Republic. The Information System on the Average Earnings: Salary Earners Sector. 68 pp. 2012. Online: http://www.ispv.cz/getattachment/e657646e-ce28-4893-83bfe6452e44441b/CR 124_PLS-pdf.aspx?disposition=attachment 